\title{
The Impact of Gender Differences in the Degree of Familiarity on Apology Strategy
}

\author{
An $\operatorname{Ran}^{1, *}$ \\ ${ }^{1}$ Foreign Language and Literature School, Wuhan University, Wuhan, China \\ *Correspondence: Foreign Language and Literature School, Wuhan University, Wuhan, China. E-mail: \\ 517131008@qq.com
}

Received: April 15, 2019 Accepted: May 19, 2019 Online Published: June 28, 2019

doi:10.5430/ijelt.v6n2p13 URL: https://doi.org/10.5430/ijelt.v6n2p13

\begin{abstract}
The purpose of this study is to see whether gender and degree of familiarity simultaneously play roles in the apology strategies employed by Chinese native speakers and to put implications on English pragmatic education of Chinese people about how to adjust English apology strategy in English context. There are 95 people participating in this study including 39 males and 56 females. The significant differences of gender only show in one situation and one apology strategy. However, the degree of familiarity can pose a profound influence on the choice of apology strategy.
\end{abstract}

Keywords: apology strategy, gender differences, degree of familiarity, Chinese

\section{Introduction}

As Spolsky (1998) declared, "language reflects, records, and transmits social differences" (p.36), it is expected men and women use language in different ways because of gender differences and the social distance may also pose effects on word choice. Researches on gender and linguistics has typically focused on language choice and gender differences, especially in sociolinguistics. Relatively little is known about whether gender and familiarity may affect some specific pragmatic use. Apology is defined as "primary social act, carrying effective meaning" (Holmes, 1995, p.199). As politeness, the aim of apology is maintaining a comfortable relation between participants. While compliments are generally regarded as positive politeness strategies, apologies are most obviously negative politeness strategies aimed at remedying the effects of an offence or FTA and restoring social harmony and equilibrium. "They are examples of negative politeness strategies or utterances concerned with maintaining or supporting the addressee's negative face" (Levinson, 1983, p.23). Apologies may be expressed by a range of strategies, with some variant of sorry the form most frequently used. The function of apology is not only in a vernacular sense, but also a technical sense of paying attention to the addressees' face needs. An apology is a fundamental speech act which is a part of human communication occurs in every culture to maintain good relations between interlocutors.

The purpose of this paper is discussing how gender and degree of familiarity influence the choice of apology strategy by conducting a questionnaire. The present study explores the effect of gender along with degree of familiarity on the use of apology strategy in Mainland China, as a non-western country with a unique system of interaction based on collectivism and traditional two-sex relationship to make strategical decision for acting and speaking appropriately with the aim of achieving the maximum benefit with the minimum cost.

\section{Literature Review}

This part introduces a theoretical basis for the paper with two aspects, namely, apology speech act, politeness theory and categorization of apology strategy. It also briefly looks back at the achievement in the works of apology and gender and degree of familiarity.

\subsection{Theoretical Framework}

There are three major theories applied in this study, the FTAs, the politeness principle and the categorization of 
apology strategy.

\subsubsection{Face-threatening Acts (FTAs)}

According to Brown and Levinson (1987), FTAs vary in terms of the kind of threat involved. Making a confession and apologizing to a friend or a stranger for attaining his/her new book threatens the positive face of the speaker himself. In this model, the seriousness or weightiness of a particular FTA is the sum of these three factors: the social distance between the speaker and the hearer, including the degree of familiarity and solidarity they share; the relative power of the speaker with respect to the hearer and the absolute raking of imposition in the culture, both in terms of the expenditure of goods or services by the hearer, the right of the speaker to perform the act, and the degree to which the hear welcomes the imposition. In this research, the degree of familiarity is a part of social distance which we consider as a variable.

\subsubsection{Politeness Principle}

The representative of this view is Leech (1983) trying to explain why people sometimes convey meaning indirectly. One very important point in his theory is the distinction he makes between an illocutionary goal and speakers' social goal. He argues that this principle cannot only solve the problem given by Grice's cooperative principle, but also can maintain harmonious relationship between hearers and speakers, which can facilitate the communication. Based on Grice's four maxims, Leech proposed a set of maxims which are called "sub-maxims". According to Leech, politeness is essentially a symmetrical, which means what is polite with respect to the hearer or some third party will be impolite with some respect to the speaker and vice versa. Marquez (2000) improved the theory by the scale of politeness, which includes the cost-benefit scale, the indirectness scale and the camaraderie scale.

\subsubsection{Categorization of Apology Strategy}

Cohen and Olshtain (1981) first categorized an apology strategy into five possible strategies: (1) an expression of an apology; (2) acknowledgement of responsibility; (3) an explanation or account; (4) an offer of repair; (5) a promise of non-recurrence. This is the most primitive for the apology strategies. In 1984, Blum-Kulka proposed another model of apology strategy. She maintained the basic framework of Cohen and Olshtain's model but developed "an expression of an apology" to "Illocutionary Force Indicating Device(IFID)" and added "denial of fault" as a new category. Holmes (1990) and Reiter (2000) made more specific categorization and added "expression lack of intent", "accepting blame" and "expressing self-deficiency" into the "acknowledgement of responsibility" part.

The design of the questionnaire in this study is the combination of the apology strategies. There are eight categorizations of apology strategies in the questionnaire: (1) Rejection of Apologizing(RA); (2) Illocutionary Force Indicating Device(IFID); (3) Explanation or Account (E) (4) Acknowledgement of Responsibility(AR); (5) Offer of Repair(OR); (6) Promise of Forbearance (PF); (7) Showing Concern (SC); (8) Minimizing the Degree of Offense (MO).

\subsection{Previous Studies}

A great amount of research has examined apologies in different languages, considering various variables such as the politeness strategies employed, the cultural values reflected in the realization of an apology, gender, the factors affecting the choice/use of a particular strategy and the strategies used by native and non-native speakers. Olshtain (1989) compared strategies by speakers of English, French, German, and Hebrew and found considerable similarities in selecting expressions of responsibility. She concluded that different languages will realize apologies in very similar ways. But is was Holmes (1989) who first explored the relationship between gender and apology strategy. She studied how women and men apology in New Zealand (1993) and found that New Zealand women apologized more than New Zealand men did, and they were apologized to more frequently than the men were. It seems likely that women regard explicit apologies for offences as more important in maintaining relationships than men do. In Holmes' study (1989), the reason to explain the differences is "men may regard apologies as signals of social distance or as devices to be used only in cases of relatively serious offences" (p.105).

Chamani (2014) investigated gender differences in the use of apologies and examines the effect of social status and social distance of on the frequency of performing and receiving apologies among males and females, in a corpus of 500 apology exchanges collected through an ethnographic method of observation in Iran. The results revealed that there were no significant gender differences in the use of apologies in Persian, and that only gender of apologizer affected the use of explanation and promise of forbearance significantly in the corpus. It was also found that males apologized to male strangers with the highest frequency while females exchanged most apologies with their female friends, and that both men and women apologized more to equals. Harb (2015) analyzed the data from native speakers of Arabic and he conclude that Arab tend to employ a diverse range of strategies when apologizing. Some 
strategies were used more frequently than others. So, he hypothesized that there would be more differences than similarities between males and females in their use of apology strategies due to gender-related issues and in light of previously conducted research that claimed more differences than similarities. The research of Ghanbari, Jamalinesari, Gowhary, and Azizfar (2015) involved 80 subjects of Kurdish bilinguals in Ilam, consisting of 40 male and 40 female subjects. They used 'Discourse Compilation Test' to test whether people in Ilam area would choice different apology strategies from western people concerning gender differences. The prime finding of this study revealed that there is no meaningful relationship between gender and apology strategies used by Ilami people. The results indicated that respondents have frequent tendency toward using "explanation", "taking responsibility" and "offer of repair" strategies.

As it has shown, little research is conducted in China and most of these researches only concern one variable (gender) for the apology strategy choice. In this paper, gender and social distance will be included as two variables to explore whether they would influence apology strategies at the same time in China.

\section{Methodology}

The purpose of the study is to examine apology strategies in Chinese context. This part open with a review of the research procedure.

\subsection{Research Questions}

Are there any differences between gender and apology strategy?

Can degree of familiarity influence the choice of apology strategy?

\subsection{Participants}

The current study involved 95 subjects, consisting 39 males and 56 females in the questionnaire survey that were chosen randomly to participate in this study.

\subsection{Procedures}

The data of this study was collected through a controlled elicitation method based on questionnaire which is a modified version of Zhang (2005)'s study (appendix A and B). The questionnaire is composed of two parts. The first part is about some basic information including gender, age, major and English level. The second part is the multiple choice including six different social contexts to indicate different degrees of familiarity. From situation 1 to situation 6 , the degree of familiarity between addresser and addressee become more and more intimate. In order to identify the apology strategies used, the researcher used tables to clarify the method used to show the other apology strategies employed in each situation and their percentage. In the present study descriptive and inferential statistical techniques Chi square test processed by SPSS 22.0 have been used to show the meaningfulness the relationship between gender and degree of familiarity between addressers and addressees in each situation and their apology strategies.

\section{Results}

In this part, the results of gender differences and degree of familiarity will be shown. Since in this study, no one choose the item "Reject Apologizing" as the apology strategy, we will not include this item in the final statistics.

\subsection{Gender}

Table 1. Chi-Square Tests of Offering of Repair in Situation 5

\begin{tabular}{lccccc}
\hline \multicolumn{7}{c}{ Chi-Square Tests } \\
\hline & Value & df & $\begin{array}{c}\text { Asymp. Sig. } \\
\text { (2-sided) }\end{array}$ & $\begin{array}{c}\text { Exact Sig. } \\
\text { (2-sided) }\end{array}$ & $\begin{array}{c}\text { Exact Sig. } \\
\text { (1-sided) }\end{array}$ \\
\hline Pearson Chi-Square & $5.541^{\mathrm{a}}$ & 1 & .019 & & \\
$\begin{array}{l}\text { Continuity Correction } \\
\text { Likelihood Ratio }\end{array}$ & 3.991 & 1 & .046 & & \\
$\begin{array}{l}\text { Fisher's Exact Test } \\
\text { Linear-by-Linear Association }\end{array}$ & 5.574 & 1 & .018 & & .030 \\
N of Valid Cases & 5.483 & 1 & .019 & & .023 \\
\hline
\end{tabular}


For the gender differences, there is no significant difference in other situations or apology strategies. But one result should be emphasized is Situation 5, for the Offering of Repair. Table 1 demonstrates the gender difference in Situation 5, offering of repair. In this situation, chi square is 5.541, bigger than the critical chi square of 3.84. The null hypothesis that gender and willingness to offer of repair are independent can be rejected. We infer that in this situation (an event between very close friends) that gender gives clue to his or her willingness to offer a repair as an apology strategy.

\subsection{Degree of Familiarity}

Table 2 is the descriptive statistic of the count of situation and apology strategy choice. It is clear that regardless of the degree of familiarity, IFID (illocutionary force indicating device) to show explicit apology is the most popular choice. And, the least people will choose minimizing offense (MO) as an apology strategy.

Table 2. The Descriptive Statistic

\begin{tabular}{|c|c|c|c|c|c|c|c|c|}
\hline \multicolumn{9}{|c|}{ Situation * AS Crosstabulation } \\
\hline & & \multicolumn{7}{|c|}{ AS } \\
\hline & & IFID & E & RA & OR & PF & $\mathrm{SC}$ & MO \\
\hline \multirow[t]{6}{*}{ Situation } & S1 & 91 & 33 & 31 & 45 & 12 & 72 & 1 \\
\hline & S2 & 89 & 26 & 46 & 59 & 12 & 67 & 2 \\
\hline & S3 & 75 & 73 & 36 & 54 & 11 & 33 & 4 \\
\hline & S4 & 82 & 26 & 38 & 59 & 24 & 39 & 5 \\
\hline & S5 & 81 & 41 & 46 & 86 & 15 & 9 & 2 \\
\hline & S6 & 79 & 49 & 63 & 49 & 39 & 38 & 3 \\
\hline Total & & 497 & 248 & 260 & 352 & 113 & 258 & 17 \\
\hline
\end{tabular}

Table 3 is the chi-square tests for apology strategy and degree of familiarity. The chi square is 167.235 , bigger than the critical chi square of 43.8. The null hypothesis that degree of familiarity and apology strategy are independent can be rejected. We infer that the degree of familiarity gives clue to his or her choice of apology strategy.

Table 3. The Chi-Square Tests of Apology Strategy and Degree of Familiarity

\begin{tabular}{|c|c|c|c|}
\hline \multicolumn{4}{|c|}{ Chi-Square Tests } \\
\hline & Value & $\mathrm{df}$ & Asymp. Sig. (2-sided) \\
\hline Pearson Chi-Square & $167.235^{\mathrm{a}}$ & 30 & .000 \\
\hline Likelihood Ratio & 167.056 & 30 & .000 \\
\hline Linear-by-Linear Association & 3.481 & 1 & .062 \\
\hline $\mathrm{N}$ of Valid Cases & 1745 & & \\
\hline
\end{tabular}

It can be inferred that gender can only predict a small part of apology strategy in particular situation, but the degree of familiarity may pose a comprehensive clue of how people choose apology strategy.

\section{Discussion}

The results of this research will be discussed in two aspects: the gender differences and the influences of degree of familiarity.

\subsection{Gender Difference}

It seems that there is no significant for overall gender different result. However, for different situations, the popular apology strategies that male and female choose still have subtle differences. Just as the table shows:

Table 4. The Percent of People Choice in S1

\begin{tabular}{ccccccccc}
\hline $\mathrm{M} \backslash \mathrm{F}$ & $\mathrm{RA}$ & $\mathrm{IFID}$ & $\mathrm{E}$ & $\mathrm{AR}$ & $\mathrm{OR}$ & $\mathrm{PF}$ & $\mathrm{SC}$ & $\mathrm{MO}$ \\
\hline $\mathrm{M}$ & $0(0 \%)$ & $38(97.44 \%)$ & $12(30.77 \%)$ & $16(41.03 \%)$ & $20(51.28 \%)$ & $7(17.95 \%)$ & $29(74.36 \%)$ & $1(2.56 \%)$ \\
$\mathrm{F}$ & $0(0 \%)$ & $53(94.64 \%)$ & $21(37.5 \%)$ & $15(26.79 \%)$ & $25(44.64 \%)$ & $5(8.93 \%)$ & $43(76.79 \%)$ & $0(0 \%)$ \\
\hline
\end{tabular}


Table 5. The Percent of Male and Female Choice in S2

\begin{tabular}{lcccccccc}
\hline $\mathrm{M} \backslash \mathrm{F}$ & $\mathrm{RA}$ & $\mathrm{IFID}$ & $\mathrm{E}$ & $\mathrm{AR}$ & $\mathrm{OR}$ & $\mathrm{PF}$ & $\mathrm{SC}$ & $\mathrm{MO}$ \\
\hline $\mathrm{M}$ & $0(0 \%)$ & $38(97.44 \%)$ & $11(28.21 \%)$ & $20(51.28 \%)$ & $21(53.85 \%)$ & $8(20.51 \%)$ & $24(61.54 \%)$ & $1(2.56 \%)$ \\
$\mathrm{F}$ & $0(0 \%)$ & $51(91.07 \%)$ & $15(26.79 \%)$ & $26(46.43 \%)$ & $38(67.86 \%)$ & $4(7.14 \%)$ & $43(76.79 \%)$ & $1(1.79 \%)$ \\
\hline
\end{tabular}

For table 4 and 5, there is no differences, both male and female believe that IFID, offering of repair and showing concern are the best choices.

Table 6. The Percent of Male and Female Choice in S3

\begin{tabular}{lcccccccc}
\hline $\mathrm{M} \backslash \mathrm{F}$ & $\mathrm{RA}$ & $\mathrm{IFID}$ & $\mathrm{E}$ & $\mathrm{AR}$ & $\mathrm{OR}$ & $\mathrm{PF}$ & $\mathrm{SC}$ & $\mathrm{MO}$ \\
\hline $\mathrm{M}$ & $0(0 \%)$ & $34(87.18 \%)$ & $28(71.79 \%)$ & $14(35.9 \%)$ & $24(61.54 \%)$ & $5(12.82 \%)$ & $14(35.9 \%)$ & $3(7.69 \%)$ \\
$\mathrm{F}$ & $0(0 \%)$ & $41(73.21 \%)$ & $45(80.36 \%)$ & $22(39.29 \%)$ & $30(53.57 \%)$ & $6(10.71 \%)$ & $19(33.93 \%)$ & $1(1.79 \%)$ \\
\hline
\end{tabular}

For table 6, both male and female choose IFID, offering of repair and explanation as the best choices. That may due to the social distance.

Table 7. The Percent of Male and Female Choice in S4

\begin{tabular}{lcccccccc}
\hline $\mathrm{M} \backslash \mathrm{F}$ & $\mathrm{RA}$ & $\mathrm{IFID}$ & $\mathrm{E}$ & $\mathrm{AR}$ & $\mathrm{OR}$ & $\mathrm{PF}$ & $\mathrm{SC}$ & $\mathrm{MO}$ \\
\hline $\mathrm{M}$ & $0(0 \%)$ & $36(92.31 \%)$ & $13(33.33 \%)$ & $16(41.03 \%)$ & $25(64.1 \%)$ & $10(25.64 \%)$ & $15(38.46 \%)$ & $4(10.26 \%)$ \\
$\mathrm{F}$ & $0(0 \%)$ & $46(82.14 \%)$ & $13(23.21 \%)$ & $22(39.29 \%)$ & $34(60.71 \%)$ & $14(25 \%)$ & $24(42.86 \%)$ & $1(1.79 \%)$ \\
\hline
\end{tabular}

From Situation 4, things are changed. Although IFID is still the most frequent apology strategy, male prefer to offer of repair and acknowledge the responsibility. On the other hand, female consider showing concern and offering of repair are the most important. That may due to the different thinking way. Male prefer more direct apology but female are more sensitive, they may perform more concern to the hearers' feelings.

Table 8. The Percent of Male and Female Choice in S5

\begin{tabular}{lcccccccc}
\hline $\mathrm{M} \backslash \mathrm{F}$ & $\mathrm{RA}$ & $\mathrm{IFID}$ & $\mathrm{E}$ & $\mathrm{AR}$ & $\mathrm{OR}$ & $\mathrm{PF}$ & $\mathrm{SC}$ & $\mathrm{MO}$ \\
\hline $\mathrm{M}$ & $0(0 \%)$ & $34(87.18 \%)$ & $14(35.9 \%)$ & $20(51.28 \%)$ & $35(89.74 \%)$ & $9(23.08 \%)$ & $6(15.38 \%)$ & $2(5.13 \%)$ \\
$\mathrm{F}$ & $0(0 \%)$ & $47(83.93 \%)$ & $27(48.21 \%)$ & $26(46.43 \%)$ & $51(91.07 \%)$ & $6(10.71 \%)$ & $3(5.36 \%)$ & $0(0 \%)$ \\
\hline
\end{tabular}

Table 9. The Percent of Male and Female Choice in S6

\begin{tabular}{lcccccccc}
\hline $\mathrm{M} \backslash \mathrm{F}$ & $\mathrm{RA}$ & $\mathrm{IFID}$ & $\mathrm{E}$ & $\mathrm{AR}$ & $\mathrm{OR}$ & $\mathrm{PF}$ & $\mathrm{SC}$ & $\mathrm{MO}$ \\
\hline $\mathrm{M}$ & $0(0 \%)$ & $35(89.74 \%)$ & $17(43.59 \%)$ & $27(69.23 \%)$ & $21(53.85 \%)$ & $18(46.15 \%)$ & $16(41.03 \%)$ & $2(5.13 \%)$ \\
$\mathrm{F}$ & $1(1.79 \%)$ & $44(78.57 \%)$ & $32(57.14 \%)$ & $36(64.29 \%)$ & $28(50 \%)$ & $21(37.5 \%)$ & $22(39.29 \%)$ & $1(1.79 \%)$ \\
\hline
\end{tabular}

Table 8 and 9 have similar tendency for male, put acknowledgement of responsibility and offering of repair at prior position. But for female, there are some differences. In table 8 , most female choose explanation and offering of repair. But in Situation 6, acknowledgment of responsibility replaces offering of repair. Maybe for female, when the relationship addresser and addressee is couple, they are not inclined to make up the mistakes because the addressee is their boyfriends, it is the responsibility of boyfriend who should forgive the girlfriend unconditionally. That may also be the reason the only one answer for "reject apologizing" appears.

\subsection{Influence of Degree of Familiarity}

For both male and female, IFID is the most frequent apology strategy that they will choose regardless of the social distance. However, the percentage changed when the degree of familiarity changed. For Situation 1 and 2 , more than $90 \%$ of people choose to show explicit apology at first, in which the social distance between speaker and hearer are the most estranged. In other situations, about $80 \%$ of people may choose IFID. Offering of repair, showing concern and acknowledgement of responsibility are in the second, third and fourth ranking as the apology strategies respectively. What surprises us most is that very few people may choose "minimizing offense" as an apology 
strategy. Just as the following charts demonstrate:

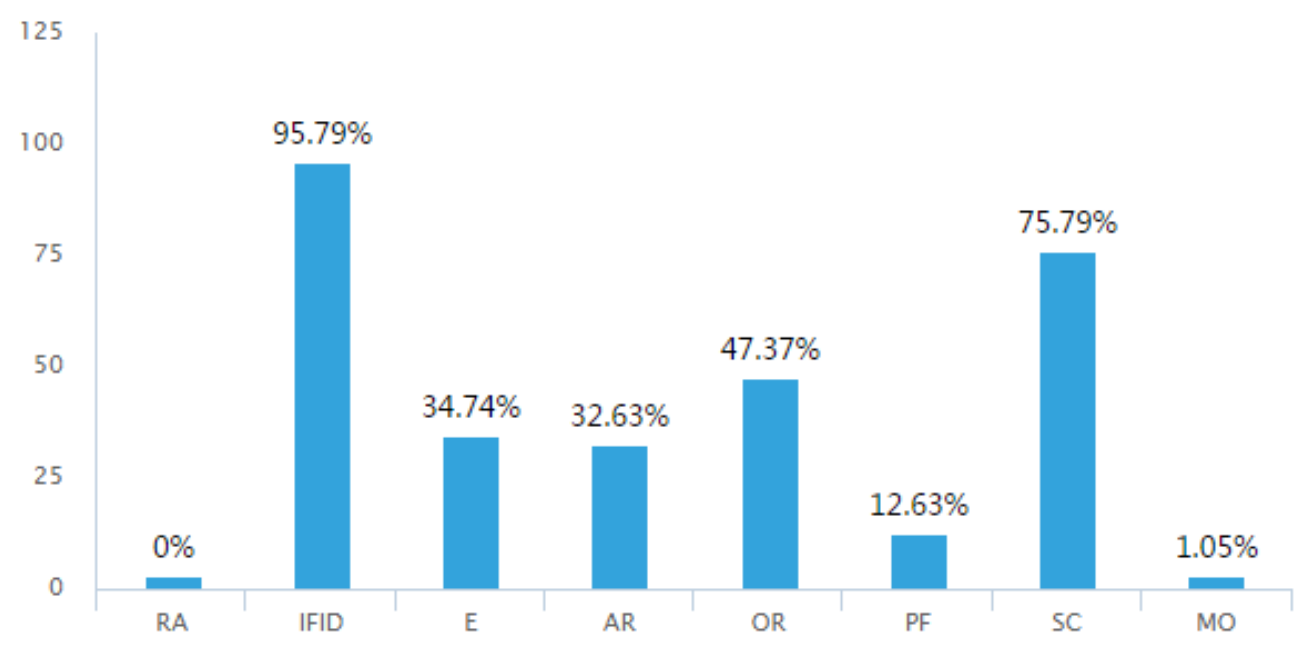

Figure 1. The Percent of People Choose Different Apology Strategies in S1

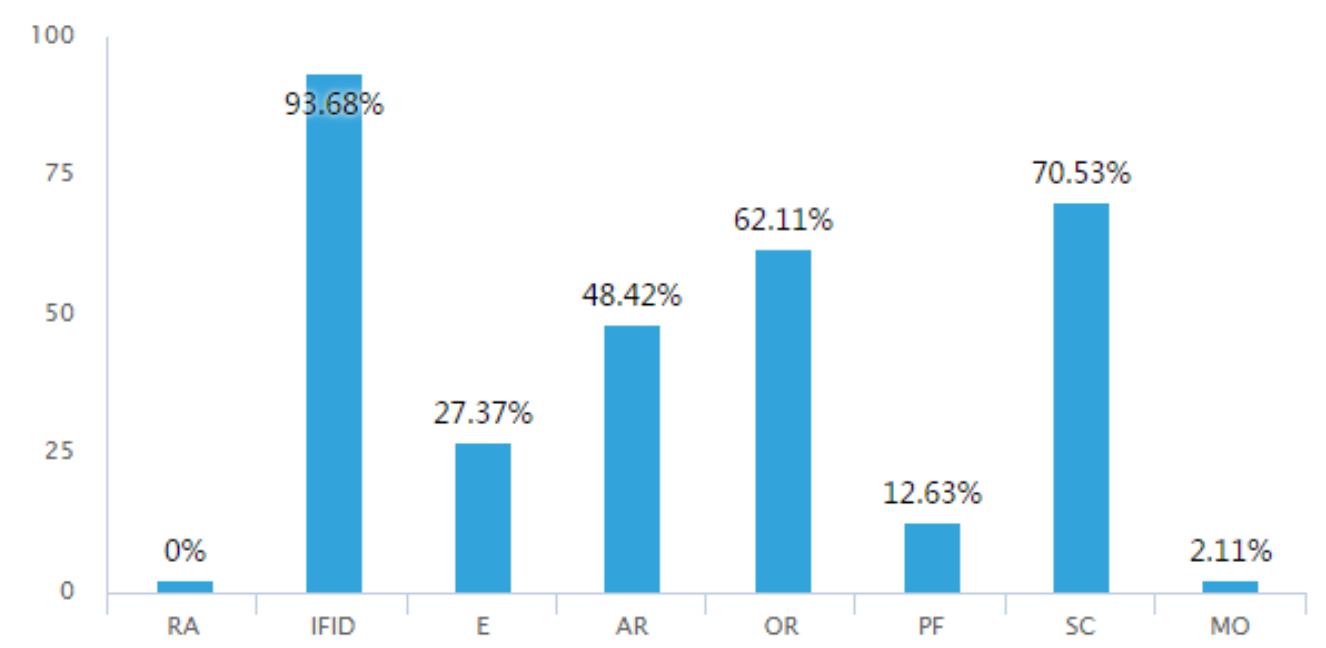

Figure 2. The Percent of People Choose Different Apology Strategies in S2

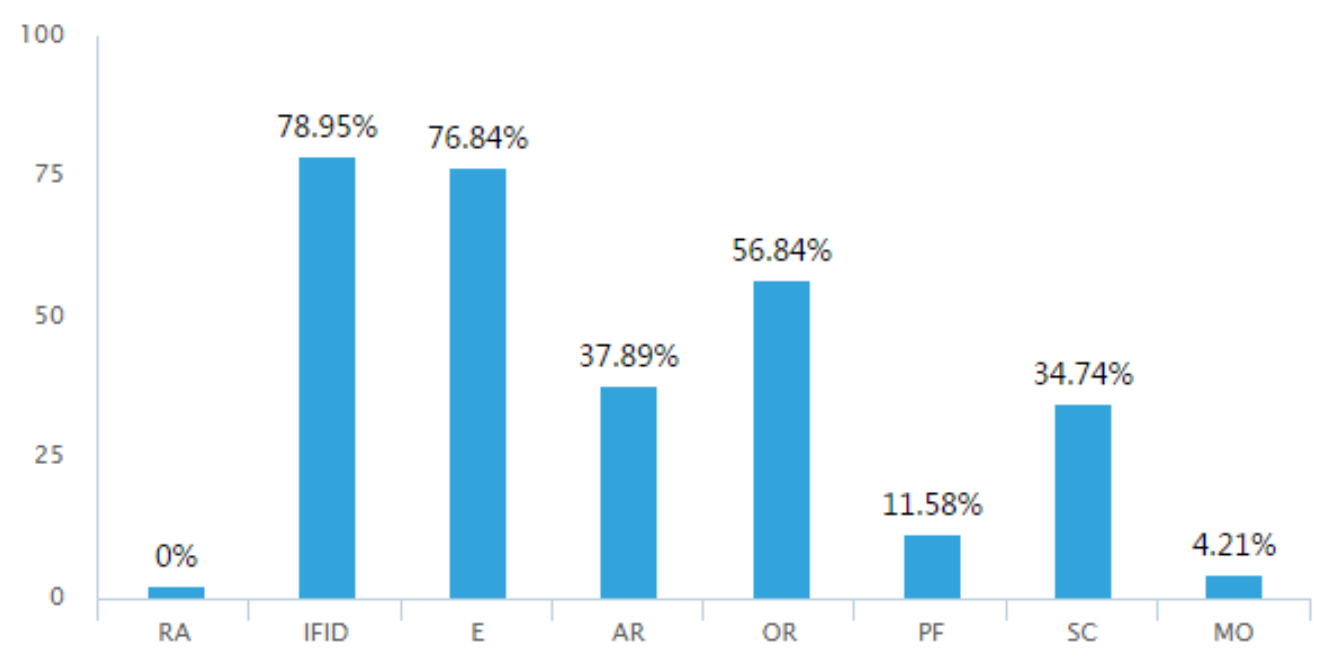

Figure 3. The Percent of People Choose Different Apology Strategies in S3 


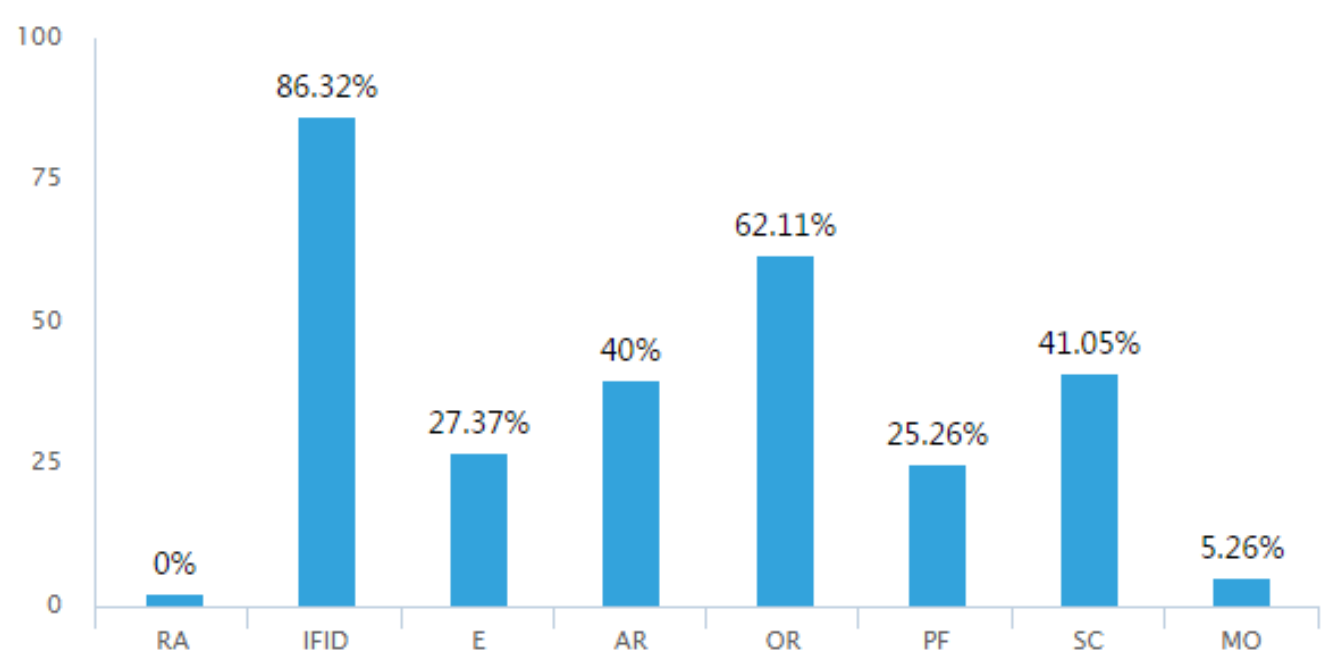

Figure 4. The Percent of People Choose Different Apology Strategies in S4

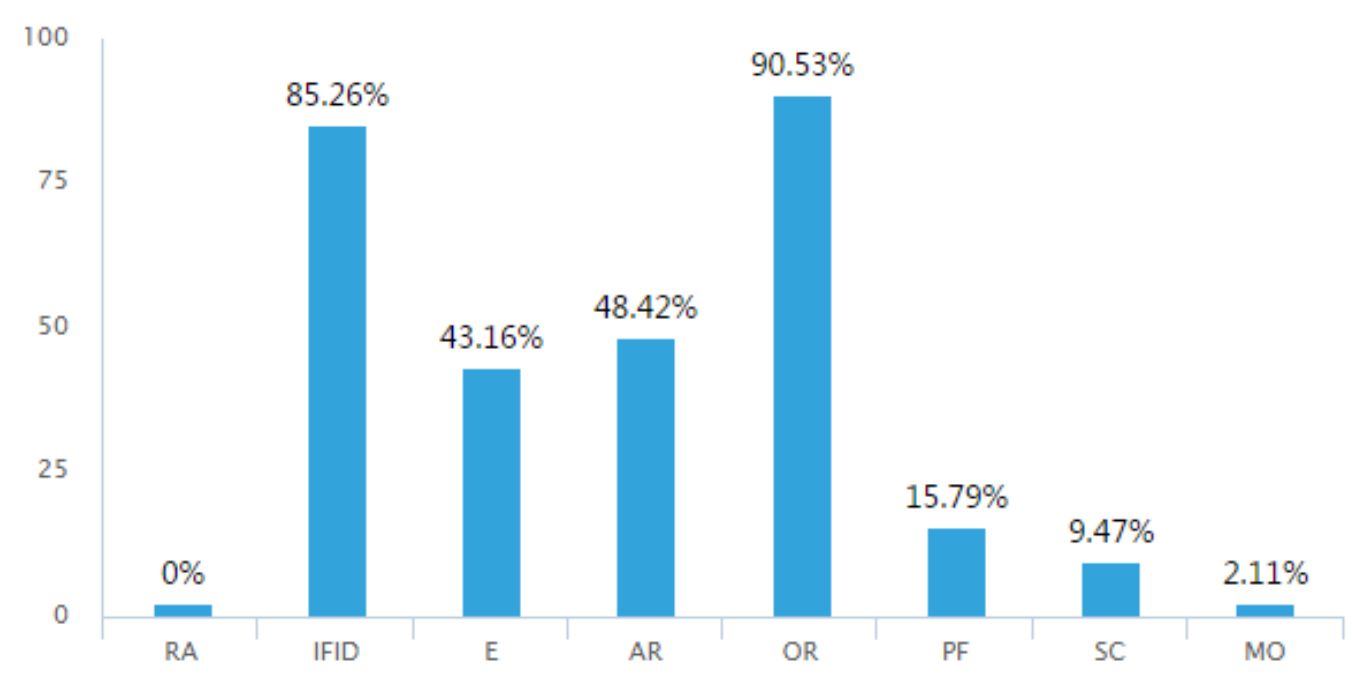

Figure 5. The Percent of People Choose Different Apology Strategies in S5

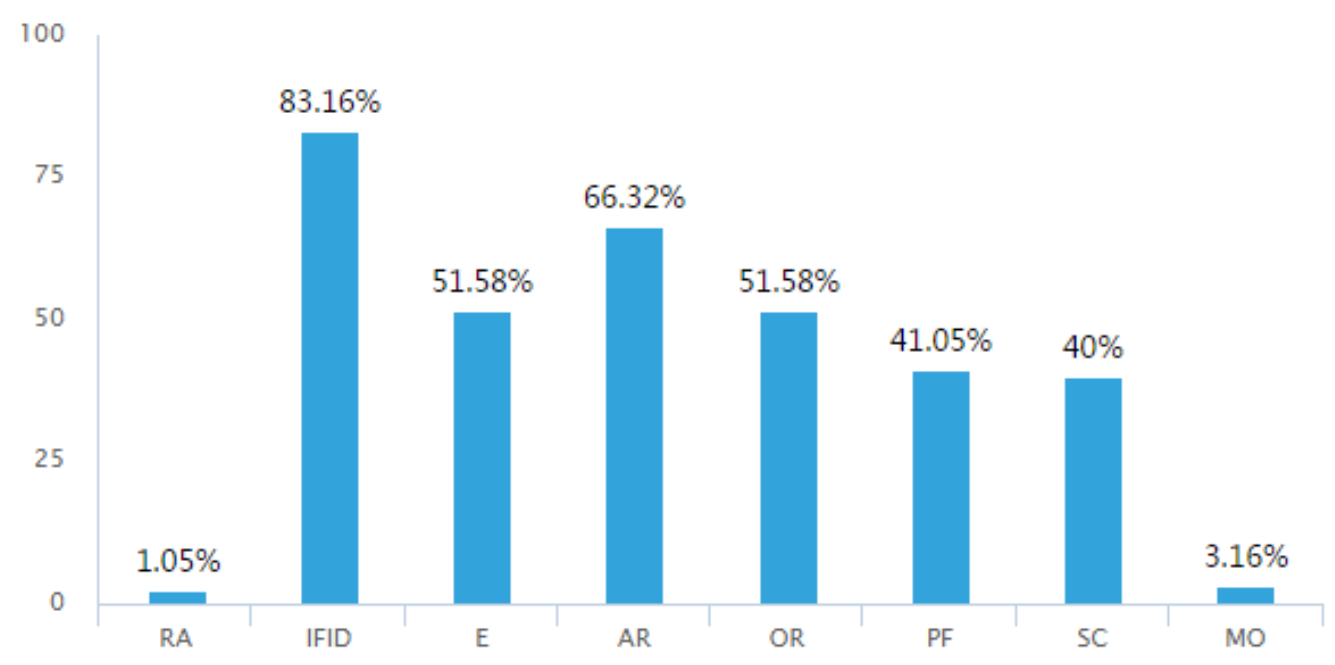

Figure 6. The Percent of People Choose Different Apology Strategies in S6 
Through this test, we could infer that it is the degree of familiarity that influence how people choose apology strategy. It seems that gender pose little influence on the apology strategy choice. Compared with previous studies of apology strategy, this study put emphasis on both gender and the degree of familiarity also the comparison is involved. For young people in Chinese society, the gender show subtle effect for the apology strategy choice but the degree of familiarity may influence of different generations in the same society.

High-context culture like Chinese society emphasizes unification. People may pay attention to social harmony and try to avoid conflicts. Once there are conflicts appear, people apologize as soon as possible. In order to avoid conflicts, people try to show their explicit apology and offer repair and concern the hearer to show their sincerity. Chinese people hold the sprit of collectivism and they want to get understood by other is an effective to get forgiven. Therefor, they tend to explain in apologizing to others.

It should be noted that Chinese people have a greater tendency to preserve "face" which can be shown from their preference for positive politeness such as "explanation" and "offer of repair" as positive politeness strategy is face-supporting.

\section{Conclusion}

This study provides us with a general sample of Chinese people in using apology strategies. In this study, it was tried to find the effect of gender and the degree of familiarity as the independent variable of the study on the use of apology strategies as the dependent variable of the study. In this study one main questionnaire set out to find the relationship between gender and degree of familiarity and apology strategies. According on data obtained on relationship these variables with apology strategies it can be said that there is no meaningful relationship between gender and apology strategies only if in some special or particular situations. The all groups used these strategies in similar way. The highest amount of frequencies in using apology strategies is related to explanation, taking responsibility, and offer of repair. Most people will show explicit apology at first. The participants used these strategies in similar ways, and the least amount of use is minimizing offense promise for forbearance. However, these results cannot be generalized to all people in China mainland. In this study participants tried to keep appositive face by the using apology strategies.

As for the degree of familiarity, there is significant difference between how close between the addresser and addressee and their apology strategy. It implicitly shows that when the relationship is closer, people will give more explanations, more willingness to acknowledge the responsibility and offering more repair. However, there are still some limitations. The most obvious one is that the male and female may show different consciousness for the degree of familiarity. Further studies can explore the relationship between gender and consciousness of the degree of familiarity before conducting the research of apology strategy.

\section{References}

Blum-Kulka, S. (1984). Request and apologies: a cross-cultural study of speech act realization patterns. Applied Linguistics, 1984(5), 196-223. https://doi.org/10.1093/applin/5.3.196

Brown, P., \& Levinson, S. C. (1987). Politeness: Some Universals in Language Usage. Cambridge: Cambridge University Press. https://doi.org/10.1515/stuf-1989-0124

Chamani, F. (2014). Gender differences in the use of apology speech act in Persian. International Journal of Linguistics, 6(6), 46-63. https://doi.org/10.5296/ijl.v6i6.6231

Ghanbari, H., Jamalinesari, A., Gowhary, H., \& Azizfar, A. (2015). Investigating apology strategy among male and female Kurdish Bilinguals at Ilam. Social and Behavioral Science, 11(2), 477-84. https://doi.org/10.1016/j.sbspro.2015.05.029

Harb, M. A. (2015). On gender and apology strategies: the case of Arabic. Gender Studies, 14(1), 224-65. https://doi.org/10.1515/genst-2016-0014

Holmes, J. (1989). Sex differences and apologies: one aspect of communicative competence. Applied Linguistics, 10(2), 194-213. https://doi.org/10.1093/applin/10.2.194

Holmes, J. (1990). Apologies in New Zealand English. Language in Society, 19(2), 155-99. https://doi.org/10.2307/4168131

Holmes, J. (1993). New Zealand women are good to talk to: an analysis of politeness strategies in interaction. 
Journal of Pragmatics, 20(2), 91-116. https://doi.org/10.1016/0378-2166(93)90078-4

Holmes, J. (1995). Women, Men and Politeness. London: Longman. https://doi.org/10.1111/1467-9481.00012

Keshani, K., \& Heidari-Shahreza, M. A. (2017). A comparative study of apology strategy uses by Iranian and German EFL learners: gender differences in focus. Journal of Applied Linguistics and Language Research, 4(1), 199-212.

Leech, G. (1983). Principles of Pragmatics. London: Longman.

Levinson, S. C. (1983). Pragmatics. New York: Cambridge University Press. https://doi.org/10.1017/CBO9780511813313

Marquez, R. (2000). Linguistic Politeness in Britain and Uruguay. Philadelphia: John Benjamin Publishing Company.

Olshtain, E., \& Cohen, A. (1983). Apology: a speech set act. Sociolinguistics and Language Acquisition, 15(2), 18-35.

Olshtain, E. (1989). Cross-Cultural Pragmatics: Requests and Apologies, NJ: Ablex Publishing.

Schumann, K. (2011). When and Why Women Apologize More than Men, (Doctoral dissertation). Waterloo: University of waterloo. https://doi.org/10.1177/0956797610384150

Spolsky, B. (1998). Sociolinguistics. Oxford: Oxford University Press.

张黎. (2005). 熟悉程度对英汉道慊策略的影响. 硕士学位论文. 大连理工大学. Unpublished paper, 张晓洁. (2012). 中国大学生汉语道鉙言语行为的性别差异研究. 硕士学位论文. 浙江大学. Unpublished paper,

\section{Appendix A. Questionnaire in Chinese}

您好! 这是一份有关性别与亲密度对道歉策略影响研究的问卷。本问卷采取匿名的方式, 除“基本信息”板块, 其余全部为多选题, 您可以选择一道题里的多个选项。请您按照您内心的真实想法进行选择。您无需担心信 息泄露的问题, 本问卷的结果仅作为学术研究使用。感谢您的参与!

基本信息

1. 您的性别:
A.男
B.女

2. 您的年龄段:
A. 18 岁以下
B. 18 25
C. $26 \sim 30$
D. $31 \sim 40$
E. $41 \sim 50$
F.51 60
G.60 岁以上

3. 英语水平
A. 大学英语四级
B. 大学英语六级
C. 专业英语四级
D. 专业英语八级
E. 未参加上述英语考试 
4. 所学专业
A.文科
B.理科
C.工科

场景假设题: 以下题目均为多选, 共 6 题。每个场景中, 您将扮演不同的角色, 与不同的人进行对话。请您 根据场景设计, 按照您的直觉和日常生活中的交往习惯进行选择。可多选您认为符合您习惯的选项。

5. 在行驶的高铁上, 你把行李放在行李架上, 可你没有拿稳, 行李掉下来砸到了另一位乘客。你可能选择的 道歉方式为: [多选题]
A.拒绝道兼
B.明确表示歉意（如：对不起；请原谅）
C. 解释说明 (如: 我没拿稳)
D. 承认应负责任（如：应该把袋子拿稳）
E.采取弥补手段（如：要不要找医生看一下）
F.保证将克制自己（如：不会再掉下来了，我保证）
G. 表达对冒犯者的关心（如：您没事吧）
H.减轻自己的冒犯程度 (如: 我拿得很好, 怎么会掉下来了呢)

6. 开学第一天, 你和刚刚结识的同学一起去吃饭, 食堂人很多, 你不小心把汤酒在了同学的身上。此时你可 能选择的道兼行为是: [多选题]
A.拒绝道兼
B.明确表示歉意（如：对不起；请原谅）
C. 解释说明 (如: 我刚刚没看到你走过来)
D.承认应付责任（如: 是我不小心）
E.采取弥补手段（如: 我给你擦擦吧）
F.保证克制自己（如：我下次一定注意）
G.表达对冒犯者的关心（如：没梁着吧？）
H.减轻自己的冒犯程度（如: 还好没惣着; 幸好污渍不是很明显）

7. 你已经答应与一位刚刚结识并见过几次面的朋友一起去参加一个聚会, 可突然有事去不了。此时你可能选 择的道兼行为是: [多选题] 

A.拒绝道歉
B.明确表示歉意（如：对不起；请原谅）
C. 解释说明 (如: 我没有时间, 老师突然找我有事)
D. 承认应付责任（如：给你添麻烦了）
E.采取弥补手段（如：改天我单独约你）
F.保证将克制自己（如：我保证以后不会发生类似的事情）
G. 表达对冒犯者的关心（如: 我没有打乱你的计划吧）
H.减轻自己的冒犯程度（如: 只少了我一个人, 没关系的)

8. 你半夜在宿舍看视频, 吵醒了正在熟睡的, 第二天要上课的室友。此时你会采取的道歉方式为: [多选题]
A.拒绝道歉
B. 明确表示歉意（如：对不起；请原谅）
C.解释说明 (如: 这视频太好看, 不小心看入迷了)
D. 承认应付责任（如: 我错了）
E.采取弥补手段（如：我马上关掉电脑，不看了）
F.保证将克制自己（如：下不为例，最后一次）
G.表达对冒犯者的关心（如：声音太大，把你吵醒了？）
H.减轻自己的冒犯程度 (如: 我已经很压制自己的声音和电脑的声音了)

9. 你不小心把果汁酒在从一位多年好友那里借来的电脑上, 导致显示器不能正常工作。此时你最可能的道歉 方式是： [多选题]
A.拒绝道歉
B.明确表示歉意（如: 对不起; 请原谅）
C.解释说明 (如: 我当时杯子没拿稳)
D.承认应付责任（如：都是我不小心）
E. 采取弥补手段（如: 我拿去修好了再还给你吧）
F.保证将克制自己 (如: 下次我要和你的电脑保持“安全距离”)
G.表达对冒犯者的关心（如：心不心疼啊？） 
H.减轻自己的冒犯程度 (如: 你的电脑用了这么久了, 显示器可能本来就有问题, 也该换一个了)

10. 你和恋爱三年的恋人一起去约会, 可你姗姗来迟让你的恋人等了一个小时。此时你最可能采取的道歉措 施是: [多选题]
A.拒绝道慊
B. 明确表示歉意（如：对不起; 请原谅）
C. 解释说明 (如: 我遇见一个熟人, 聊了几句/我化妆花了点时间)
D. 承认应负责任 (如: 是我不好, 让你等了这么久)
E. 采取弥补手段（如：你说吧, 怎么惩罚我, 我补偿你）
F.保证将克制自己（如: 下次我一定不会迟到了, 我保证)
G.表达对冒犯者的关心（如：你等了很久吧？）
H.减轻自己冒犯程度 (如: 这是我这么长时间里第一次迟到)

十分感谢您的配合!

\section{Appendix B. Questionnaire in English}

The questionnaire is to investigate the impact of gender differences in the degree of familiarity on apology strategy selection. Besides the basic information, all the questions are multiple choices, which means you can choice the answers as many as you want. The questionnaire is anonymous. All the results are for academic purpose only. Thank you for your cooperation!

Basic Information

1 Gender: A. Male B. Female

2 Age:
A.Under18
B. 18 25
C. $26 \sim 30$
D. $31 \sim 40$
E. $41 \sim 50$
F.51 60
G. Above 60

3 English Level:
A.CET 4 B. CET 6
C. TEM 4
D. TEM 8
E. Other
4 Major: A. Art
B. Science
C. Engineering

\section{Introduction:}

There are six situations in which you may take different roles to select the possible apology strategies. You can choice more than one answer for a question.

5 You have put a luggage in a train. But you didn't hold it and it falls down and hit another passenger. At that time, you should ( )
A. Reject apologizing
B. Apologize by saying (Sorry; I'm very sorry)
C. Explain by saying (I didn't hold it steadily) 
D. Acknowledge responsibility by saying (It's my fault. I should hold it steadily)

E. Offer repair by saying (Shall we go to the hospital?)

F. Promise forbearance by saying (I promise it won't fall again)

G. Show concern by saying (Are you OK?)

H. Minimize offense by saying (I hold it really well, why it falls down?)

6 The first day of your university, you newly met a classmate to have a meal together. There are so many people in the dining hall and you get your soup poured onto your classmate's shirt. At that time, you should ( )

A. Reject apologizing

B. Apologize by saying (Sorry; I'm very sorry)

C. Explain by saying (I didn't see you right now)

D. Acknowledge responsibility by saying (It's my fault)

E. Offer repair by saying (Let me help you clean up it)

F. Promise forbearance by saying (I promise I will be careful next time)

G. Show concern by saying (Are you OK?)

H. Minimize offense by saying (The stain is not so clear. Thank God you're not hurt)

7 A friend of you, with whom you have hung out several times, asks you to go to a party. A promise to come, but can not chow up because of an urgent event. At this time, you should ( )
A. Reject apologizing
B. Apologize by saying (Sorry; I'm very sorry)
C. Explain by saying (My teacher wants to talk with my now)
D. Acknowledge responsibility by saying (It's my fault)
E. Offer repair by saying (I will invite you for a dinner next time)
F. Promise forbearance by saying (I promise it won't happen again)
G. Show concern by saying (Did I break your plan?)
H. Minimize offense by saying (It's OK only I couldn't come to the party)

8 You watch a video at mid-night and wake up your roommate who is going to have a class next morning. At this time, you should ()
A. Reject apologizing
B. Apologize by saying (Sorry; I'm very sorry)
C. Explain by saying (The video is too funny and I can't help laughing)
D. Acknowledge responsibility by saying (It's my fault)
E. Offer repair by saying (I will turn off the laptop right now)
F. Promise forbearance by saying (I promise I won't wake up you again)
G. Show concern by saying (My voice wakes up you?)
H. Minimize offense by saying (I've tried to turn the volume down)

9 You and Tom have been friends for many years. You borrowed Tom's laptop but you poured juice to the laptop and the browser didn't work anymore. At this time, you should say ( )

A. Reject apologizing 
B. Apologize by saying (Sorry; I'm very sorry)

C. Explain by saying (I didn't hold the glass of juice steadily)

D. Acknowledge responsibility by saying (It's my fault)

E. Offer repair by saying (I will fix it)

F. Promise forbearance by saying (I will never use your laptop again )

G. Show concern by saying (Are you OK?)

H. Minimize offense by saying (Your laptop has been used for a long time, maybe there are some problems with the browser)

10 You and your boyfriend/girlfriend have a date (You have fell in love for 3 years). But you are late and your boyfriend/girlfriend has been waiting for 20 minutes. At this time, you should ( )
A. Reject apologizing
B. Apologize by saying (Sorry; I'm very sorry)
C. Explain by saying (I met an acquaintance/I spend too much time to make up)
D. Acknowledge responsibility by saying (It's my fault. I shouldn't keep you waiting)
E. Offer repair by saying (What can I do for compensate?)
F. Promise forbearance by saying (I promise I won't be late again)
G. Show concern by saying (Have you been waiting for long time?)
H. Minimize offense by saying (This is the first time I be late)

Thank you! 